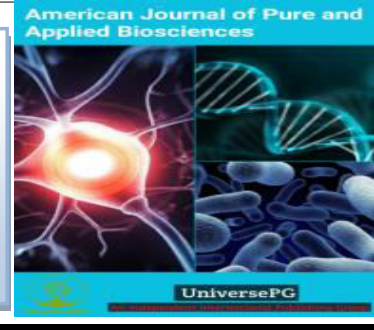

\title{
Bacterial Degradation of Synthetic Dye by Pseudomonas sp. Obtained from Dyeing Mill Effluent
}

\author{
Md. Zobaidul Hossen ${ }^{1}$, Selina Akhter ${ }^{1}$, Taslima Rahman ${ }^{1}$, Tahmina ${ }^{1}$, and Mahmuda Khatun ${ }^{2}$ \\ ${ }^{1}$ Department of Microbiology and Biochemistry, Bangladesh Jute Research Institute, Dhaka-1207, Bangladesh and ${ }^{2}$ Product \\ Development Division, Bangladesh Jute Research Institute, Dhaka-1207, Bangladesh. \\ *Correspondence: zobaidulgeb@gmail.com (Md. Zobaidul Hossen, Scientific Officer, Department of Microbiology and \\ Biochemistry, Bangladesh Jute Research Institute, Dhaka-1207, Bangladesh).
}

\begin{abstract}
Environmental pollution is one of the major concerns of today's world. Due to rapid industrialization and urbanization, a large number of wastes are generated and discharged into the environment and causing major pollution problems. For obtaining reactive dye decolorizing bacterial isolates, effluent samples were collected from a dyeing mill. From bacterial pure culture, 10 isolates were selected for screening. Screening of these isolates for the capability to decolorize and degrade reactive dye was performed in a nutrient broth medium containing reactive dye. 6 isolates among these bacterial isolates showed dye decolorizing ability within 120 hours of incubation. These isolates were further identified based on cultural, morphological, and biochemical characteristics. These characteristics indicated that these six bacterial isolates were distributed to the bacterial genus of Bacillus (2 isolates), Pseudomonas (2 isolates), Aeromonas (1 isolate), and Alcaligenes (1 isolate). For the study of dye decolorization and degradation, Reactive Dark Blue dye used in jute and textile industries was chosen. Pseudomonas, a prominent dye decolorizing isolate during screening, was taken for the optimization of different physicochemical parameters. This bacterium decolorized and grew well up to $500 \mathrm{mgL}^{-1}$ of Reactive Blue dye. Pseudomonas sp. showed noteworthy decolorization of approximately $84 \%$ at $200 \mathrm{mgL}^{-1}$ of dye concentration after $96 \mathrm{~h}$ of incubation. The optimum temperature for dye degradation was at $37{ }^{\circ} \mathrm{C}$. The maximum level of decolorization for Pseudomonas sp. was observed at $\mathrm{pH}$ 8.0. This isolate showed better decolorization extent under static conditions rather than shaking conditions. This result indicated that the dye had been utilized by this bacterial isolate. It can be concluded that Pseudomonas is a prospective candidate in the biodegradation of Reactive Blue dye and might be useful in bioprocess technology used for the bioremediation of dyeing mill effluents.
\end{abstract}

Keywords: Bacteria, Decolorization, Biodegradation, Reactive dye, Dying mill, and Pseudomonas sp.

\section{INTRODUCTION:}

Effluent from dyeing industries is one of the main sources of aquatic environmental pollution among many pollutants. Different industries like textile, cosmetic, pharmaceutical, jute, food and paper mills

UniversePG I www.universepg.com utilize synthetic dyes extensively (Pandey et al., 2007; Kant, 2012). Usually dyes are not biodegraded easily for complex molecular structures (Dellamatrice et al., 2017). Total usages of various dyes and pigments in textile and jute industries is about 10,000 and total yearly production is over $7 \times 10^{5}$ tons (Daneshvar et al., 
2007; Celia and Suruthi, 2016). For rapid industrialization, the demand for dye is rising immensely (Mohan et al., 2002), and there is huge utilization of reactive dyes in textile and jute industries for high wet fastness, various color shades, brilliant colors, easier application and less energy consumption (Shah et al., 2013). Azo, anthraquinone and phthalocyanine are the most common type among the reactive dyes (Axelsson et al., 2006) and majority of these are toxic, mutagenic and carcinogenic (Stiborova et al., 2013). Inappropriate release of effluents containing reactive dyes has detrimental effects on the aquatic environment for metals, aromatics, chlorides, etc. present in dyes. This may extensively hamper photosynthesis for reduced penetration of light (Celia and Suruthi, 2016).

Different physico-chemical methods like adsorption, oxidation, coagulation-flocculation and electrochemical methods are generally used for the remediation of dye from dyeing mill effluents (Lin and Peng, 1994) but these have many demerits like highsludge production, high cost and by-products formation (Celia and Suruthi, 2016). But bioprocessing can surmount these drawbacks for being cost effective and ecofriendly (Kurade et al., 2017). So development of effective process for removal of dyes from wastewater is badly needed.

Bioprocessing has gained growing interest as a feasible alternative owing to cost effectiveness, less sludge generation and environment-friendly nature. Bacteria, yeast, fungi and algae are competent for decolorizing various dyes (Ayed et al., 2010; Kabra et al., 2011; Patel et al., 2013; Saratale et al., 2013; Veena et al., 2019) and recent studies have given importance on using these microorganisms (Mishra and Malik, 2014; Shen et al., 2015; Kurade et al., 2017; Veena et al., 2019). Moreover, bacteria can not only degrade but also totally mineralize reactive dyes under suitable conditions (Jadhav et al., 2011; Kurade et al., 2012; Barapatre et al., 2017). Bacterial hydroxylase and oxygenase enzymes can degrade aromatic amines, intermediate metabolites produced in degradation of dyes and pigments (Pandey et al., 2007; Wanyonyi et al., 2017).

In Bangladesh, textile and jute sectors are two important sectors from agricultural, industrial, econo- mic and commercial perspectives. Bangladesh is a prominent manufacturer and exporter of jute and jute diversified products. The export market is becoming attractive gradually as people around the world are more getting environmentally conscious. Moreover, Bangladesh is second in garment-manufacturing and this is the largest sector for earnings foreign currency and employment generation (Farhana et al., 2015; Shuchismita and Ashraful, 2015). These industries use huge amount of dyes and discharge wastewater without treatment (Chindah et al., 2004) and the parameters for physicochemical property are found much higher than the recommended value of Department of Environment (Shuchismita and Ashraful, 2015).

Reactive dyes present in subsurface water make them aesthetically obnoxious and health hazards like dermatitis, mucous membrane, perforation of nasal septum and respiratory tract irritation; toxicological effects are the results (Islam et al., 2011; Yadav, 2014; Rovira and Domingo, 2019). For the remediation of reactive dye generated toxicity, a bioprocess - that is effective and sustainable is needed and obtain-ning reactive dye-degrading bacteria from effluent is significant. Numerous studies have shown microbial dye decolorization through absorption and degradation (Mishra and Malik, 2014; Shen et al., 2015; Kurade et al., 2017; Veena et al., 2019), further studies are needed to develop biotechnological process for the degradation and detoxification of dye containing effluents.

Isolation of bacteria from effluent of untreated dyeing industry was performed in the present study. These dye decolorizing bacteria were further identified. Reactive Blue dye applied in dyeing purpose in jute and textile industries was used for optimizing various physicochemical parameters for decolorization.

\section{MATERIALS AND METHODS:}

2.1. Chemicals - For this study, a reactive dyenamely Reactive Dark Blue dye was collected from Four $\mathrm{H}$ Dyeing Industry located at Chittagong, Bangladesh. All other chemicals were bought from Sigma Aldrich, India.

2.2. Sample collection - For sample collection, in sterile vials were used. Samples were collected from 
effluent of dyeing industry located at Chittagong, Bangladesh and transported to the laboratory as early as possible. These effluent samples were stored at $4^{\circ} \mathrm{C}$ for the experiment.

2.3. Isolation, screening and identification of dye decolorizing bacteria - Samples collected from dyeing mill effluent were serially diluted up to $10^{4}$ times. These diluted samples were separately cultured as described by Hossen et al. (2019). Nutrient agar plates were used for this purpose. For getting pure culture, 10 colonies of bacterial isolates were selected randomly. Screening for dye decolorizing bacterial isolates was carried out for 7 days using the reactive dye as previously described (Hossen et al. 2020). Usually 100-300 $\mathrm{mg} \mathrm{L}^{-1}$ dye concentration is used for decolorization study (Lalnunhlimi and Krishnaswamy, 2016). After screening, dye decolorizing bacteria were identified. Bacterial identification was done based on morphological, cultural and biochemical characteristics and according to Bergey's Manual of Systematic Bacteriology (Rahman et al., 2019; Staley et al., 2001).

2.4. Measurement of decolorization extent - Freshly cultured inoculum $(5 \%, \mathrm{v} / \mathrm{v})$ was inoculated into $50 \mathrm{ml}$ conical flask of dye containing sterile nutrient broth. The experiment was conducted at $37{ }^{\circ} \mathrm{C}$. This study was carried out for $96 \mathrm{~h}$ under static condition. $2 \mathrm{ml}$ dye containing culture was collected and centrifuged at $8000 \mathrm{rpm}$ for $10 \mathrm{~min}$. Decolorization percentage was estimated by measuring the absorbance at $635 \mathrm{~nm}$ $\left(\lambda_{\max }\right)$ using a UV-visible spectrophotometer (Shimadzu UV-1800, Japan). Decolorization extent was measured by the following equation:

Decolorization extent $(\%)=\frac{\text { OD1 }- \text { ODt }}{\text { OD1 }} \times 100$

Here, OD1 is the initial absorbance before decolorization, ODt is the absorbance after decolorization.

2.5. Effects of different physicochemical parameters on dye decolorization - Effects of different physicochemical parameters on dye decolorization was observed and optimized. From the bacteria, one isolate from the genus Pseudomonas (isolate 9), which was prominent decolorizer during screening was selected. The effect of initial dye concentration was studied in nutrient broth media having 50 to 1000 $\mathrm{mgL}^{-1}$ of dye.

$\mathrm{pH}$ of the media was adjusted to 7.0 and experiment was conducted at $37^{\circ} \mathrm{C}$. Effect of incubation period on dye degradation was observed for $96 \mathrm{~h}$ using $200 \mathrm{mg}$ $\mathrm{L}^{-1}$ of dye containing media at $37{ }^{\circ} \mathrm{C}$. $\mathrm{pH}$ of the nutrient broth media was 7.0. To estimate the optimum temperature, the study was done at 30,37 and $45^{\circ} \mathrm{C}$. The initial $\mathrm{pH}$ of the media was adjusted to7.0. The effect of initial $\mathrm{pH}$ on the decolorization was investigated and for this media were adjusted to $\mathrm{pH}$ 5.0 to 9.0. The experiment was done at $37{ }^{\circ} \mathrm{C}$.

2.6. Statistical analysis - For statistical analysis, $t$ test was used and a $P$ value of $<0.05$ was considered as statistically significant. Data were presented as the means of repeated experiments $(n=5)$.

\section{RESULTS AND DISCUSSION:}

3.1. Isolation, screening and identification of reactive dye decolorizing bacterial isolates Heterotrophic bacteria were isolated from dyeing mill effluent. From the nutrient agar plate used for bacterial culture, ten isolates were selected randomly. Investigation for dye decolorizing capability of these bacterial isolates was done. Reactive Blue dye (200 $\mathrm{mgL}^{-1}$ ) was used for screening of dye decolorization of these 10 isolates and was carried out in dye containing nutrient broth media for seven days (Table 1).

Six isolates showed positive result in the decolorization of dye and were chosen for further study. Decolorization percentage and number of dye decolorizing bacteria increased with the extending incubation period. Decolorizing isolates were identified on the basis of cultural, morphological and biochemical characteristics. These characteristics indicated two bacterial isolates as Pseudomonas, two as Bacillus, one as Alcaligenes and one as Aeromonas. The characteristics used for dye degrading bacterial identification are summarized in Table 2. Pseudomonas sp. (isolate 9) was chosen for future study as it was a prominent dye decolorizer during screening. 
Table 1: Screening of dye degrading bacteria following incubation at $37^{\circ} \mathrm{C}$ for $170 \mathrm{~h}$

\begin{tabular}{|c|c|c|c|c|c|c|c|c|c|c|c|}
\hline Dye & Observation period & 1 & 2 & 3 & 4 & 5 & 6 & 7 & 8 & 9 & 10 \\
\hline \multirow{7}{*}{$\begin{array}{c}\text { Reactive Dark } \\
\text { Blue }\end{array}$} & $24 \mathrm{~h}$ & - & - & - & - & - & - & - & + & - & - \\
\hline & $48 \mathrm{~h}$ & - & - & - & + & - & - & - & + & + & - \\
\hline & $72 \mathrm{~h}$ & - & - & - & + & - & - & - & + & + & + \\
\hline & $96 \mathrm{~h}$ & - & - & - & + & - & - & - & + & + & + \\
\hline & $120 \mathrm{~h}$ & - & - & - & + & + & - & + & + & + & + \\
\hline & $144 \mathrm{~h}$ & - & - & - & + & + & - & + & + & + & + \\
\hline & $170 \mathrm{~h}$ & - & - & - & + & + & - & + & + & + & + \\
\hline
\end{tabular}

Table 2: Morphological and biochemical characteristics of bacterial isolate

\begin{tabular}{|l|c|}
\hline $\begin{array}{c}\text { Morphological and biochemical } \\
\text { tests }\end{array}$ & Bacterial isolate 9 \\
\hline Shape & + \\
\hline Motility & + \\
\hline Catalase production & + \\
\hline Oxidase production & - \\
\hline Gram staining & - \\
\hline Indole test & + \\
\hline Methyl red test & - \\
\hline Voges-Proskauer test & K/A \\
\hline $\begin{array}{l}\text { Triple Sugar Iron Agar test } \\
\text { (Slant/Batt) }\end{array}$ & + \\
\hline Citrate utilization & - \\
\hline Maltose fermentation & + \\
\hline Lactose fermentation & Pseudomonas sp. \\
\hline Glucose fermentation & - \\
\hline Spore test & \\
\hline Bacterial genus & \\
\hline
\end{tabular}

Here, $\mathrm{K} / \mathrm{A}=$ Red/Yellow

\subsection{Effects of incubation period on dye decolor-} ization - We studied the effects of incubation period on decolorization of Reactive Blue dye by this bacterial isolate. It was observed by measuring dye decolorization extent at different intervals of time at $37^{\circ} \mathrm{C}$ and $\mathrm{pH} 7.0$ (Fig 1). The results recorded for Pseudomonas showed that there was a sharp increase in dye decolorization at 24 hours and the decolorization percentage was more than $67 \%$ of the entire UniversePG I www.universepg.com decolorization percentage. After 24 hours with the extended incubation period, the progress in color removal grew slightly. The difference between the result recorded at 72 hours and 96 hours was only $2 \%$ color removal. In literature, Pseudomonas aeruginosa decolorized Orange 3R dye by $93.06 \%$ (Jadhav et al., 2011).

3.3. Effects of initial dye concentration on dye decolorization - Initial dye concentration is an important parameter in decolorization study because it has powerful inhibitory effects on dye decolorization (Kalme et al., 2007). The dye decolorization extent reduced with increase of initial concentration of dye. Decolorization activity of Pseudomonas sp. was studied using various concentrations of Reactive Blue dye ranging from 50 to $1000 \mathrm{mg} \mathrm{L}^{-1}$ (Fig 2). From the result it can be concluded that with extended initial dye concentration, the decolorization percentage decreased. Highest decolorization obtained by Pseudomonas sp. used in this study was approximately $82 \%$ with 200 $\mathrm{mg} \mathrm{L}^{-1}$ of Reactive Blue dye. In previous literature for the decolorization of azo direct blue 151 and azo direct red 31, Bacillus species showed maximum decolorization (95-97\%) for $200 \mathrm{mg} \mathrm{L}^{-1}$ of dye concentration (Lalnunhlimi and Krishnaswamy, 2016). At 500mg L $\mathrm{m}^{-1}$ of the dye concentration decolorization decreased drastically. Decolorization was completely inhibited when $1000 \mathrm{mg} \mathrm{L}^{-1}$ of dye was used.

\subsection{Effects of temperature on dye decolorization -} Decolorization extends of Pseudomonas sp. was observed using different temperature ranging from 30 to $45{ }^{\circ} \mathrm{C}$. The temperature recorded for highest dye decolorization by Pseudomonas sp. was $37{ }^{\circ} \mathrm{C}$. More- 
over, a significant and appreciable decolorization was obtained at $30{ }^{\circ} \mathrm{C}$ (Fig 3). The optimum temperature for maximum Reactive Blue dye decolorization by this isolate was in harmony with the decolorization by Pseudomonas sp. for malachite green, fast green, methylene blue and congo red (Mali et al., 2000) and decolorization of fast red by B. subtilis (Mona and

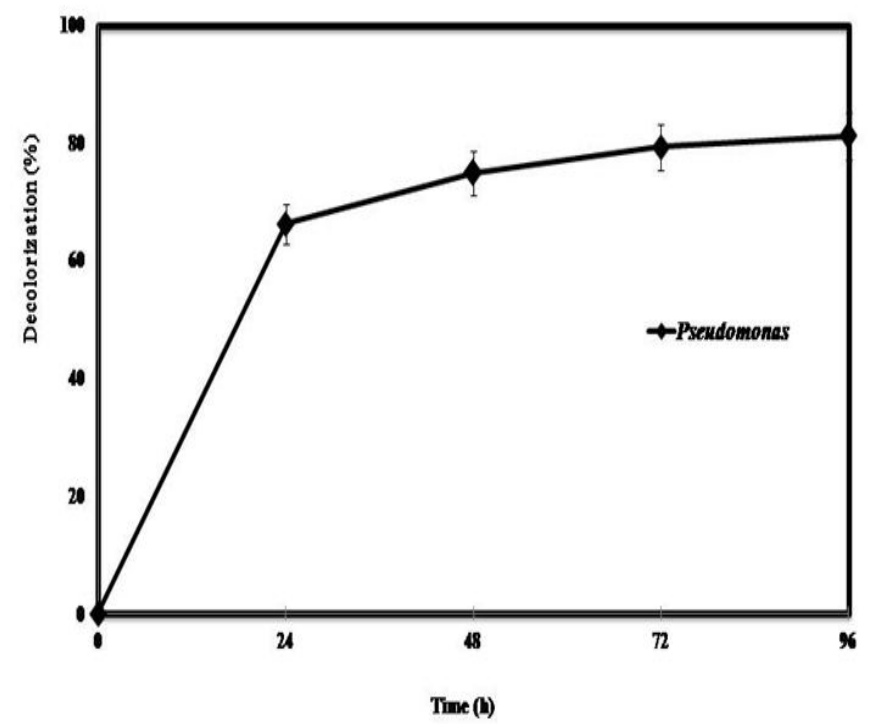

Fig 1: Effects of incubation period on dye decolorization. The concentration of the dye was 200 $\mathrm{mg} \mathrm{L}^{-1}$. The decolorization extent was measured for 96 $\mathrm{h}$ of cultivation at $37^{\circ} \mathrm{C}$ with the initial $\mathrm{pH} 7.0$ and $5 \%$ inoculum.

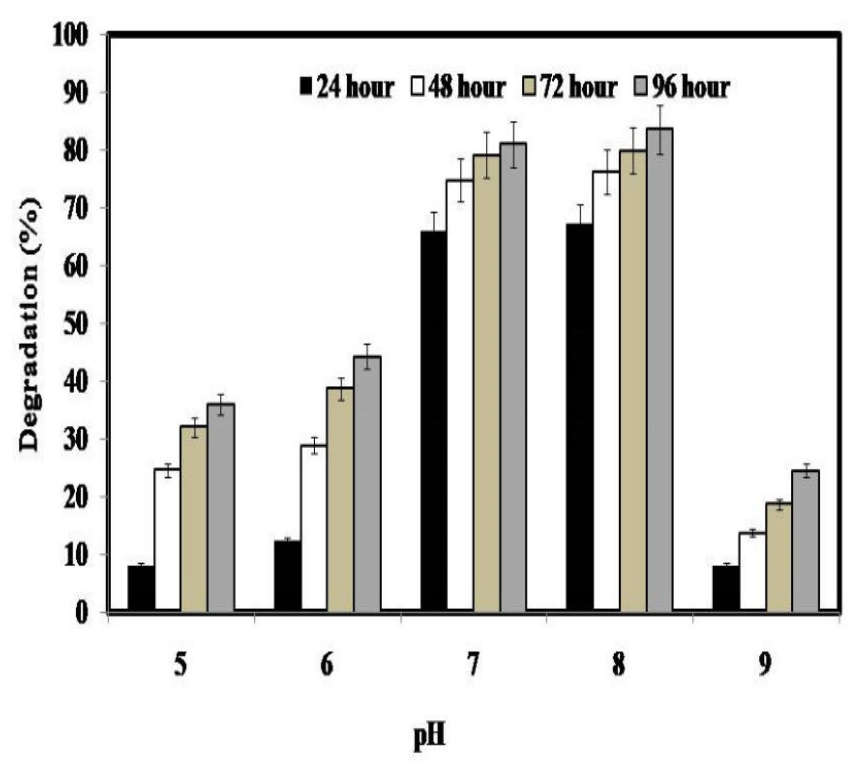

Fig 3: Effects of temperature on dye decolorization after $96 \mathrm{~h}$ of incubation with 5\% inoculum. The initial dye concentration and initial $\mathrm{pH}$ were adjusted to 200 $\mathrm{mgL}^{-1}$ and 7.0, respectively.
Yusef, 2008; Uddin et al., 2017). Decolorization activity was strongly inhibited at $45^{\circ} \mathrm{C}$. This might be due to loss of cell viability or enzymes deactivation used for decolorization (Çetin and Dönmez, 2006). From the study, it can be concluded that for dye decolorization by this isolate, $30-37^{\circ} \mathrm{C}$ might be the best temperature.

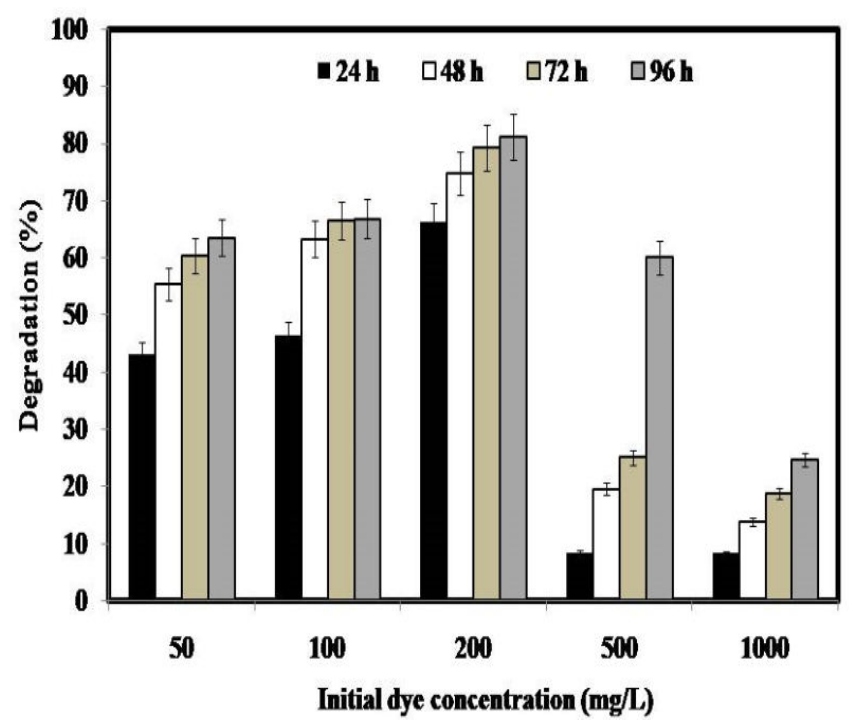

Fig 2: Effects of initial dye concentrations on dye decolorization after $96 \mathrm{~h}$ of incubation with $5 \%$ inoculums. The initial $\mathrm{pH}$ in and the temperature were 7.0 and $37^{\circ} \mathrm{C}$, respectively.

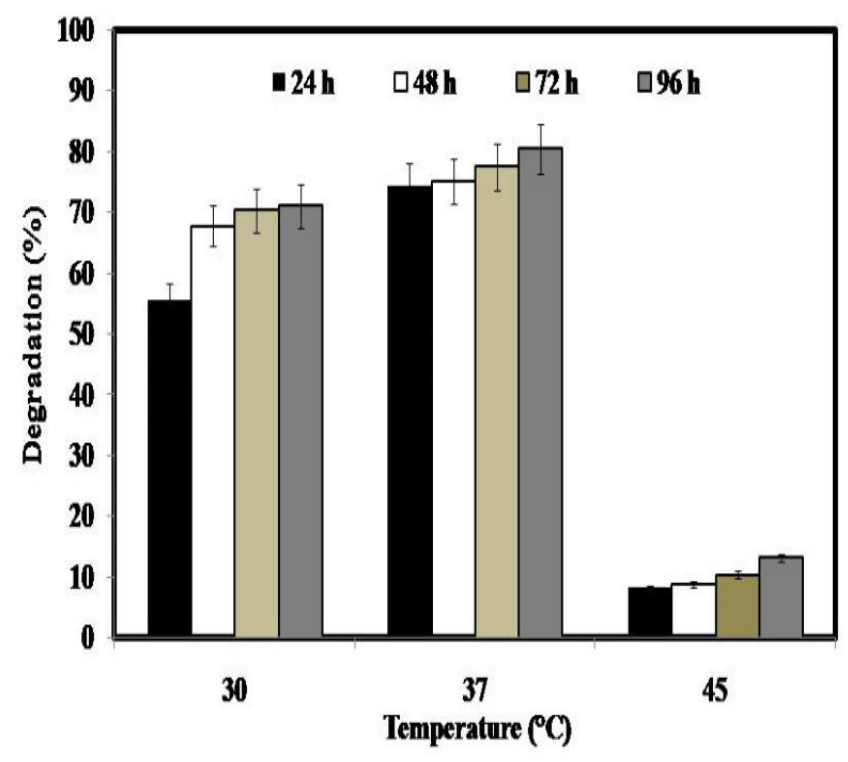

Fig 4: Effects of $\mathrm{pH}$ on dye decolorization after 96 $\mathrm{h}$ of incubation with $5 \%$ inoculum. The initial dye concentration and the temperature were $200 \mathrm{mgL}^{-1}$ and $37^{\circ} \mathrm{C}$, respectively. 
3.5. Effects of $\mathbf{p H}$ on dye decolorization - We optimized the decolorization $\mathrm{pH}$ as it is an important environmental parameter affecting the decolorization of dye by bacteria. The effect of initial $\mathrm{pH}$ across a range of $\mathrm{pH}$ values from 5.0 to 9.0 on decolorization by Pseudomonas sp. was investigated using Reactive Blue dye. The maximum dye decolorization by this isolate was obtained at $\mathrm{pH} 8.0$ (Fig 4). However, significant level of dye decolorization (82\%) was also supported by $\mathrm{pH}$ 7.0. Moreover, better dye decolorizations by this bacterial isolate were obtained at $\mathrm{pH}$ 5.0-9.0. This finding indicated that this isolate could decolorize reactive dye within a wide range of $\mathrm{pH}$, indicating that this strain is a potential organism for practical bioprocessing application. The optimum $\mathrm{pH}$ observed for dye decolorization by Pseudomonas sp. in present study is comparable to the decolorization of Bacillus spp., Enterobacter sp. and A. faecalis PMS-1 (Shah et al., 2012; Lalnunhlimi and Krishnaswamy, 2016). Ability of bacterial isolates to $\mathrm{pH}$ tolerance is very significant as under alkaline condition binding of reactive azo dyes with jute and cotton fibre occur through addition or substitution process (Wang et al., 2013).

\section{CONCLUSION:}

Reactive dye degrading bacteria were isolated from effluent of dyeing industry and identified based on morphological and biochemical characteristics. Biodegradation depends on various physico-chemical parameters. Pseudomonas sp. showed significant dye decolorizing activity and this could tolerate up to 1000 $\mathrm{mg} \mathrm{L}^{-1}$ of Reactive Blue dye. For high degradative and decolorizing ability against reactive dye, it can be predicted that Pseudomonas sp. has a suitable application potential for biotransformation of dyeing industry effluents.

\section{ACKNOWLEDGEMENT:}

The authors would like to convey their heartiest thanks to all officers and lab assistants in BJRI for their continuous support and help to make this work a successful.

\section{CONFLICTS OF INTEREST:}

The author (s) declared no potential conflicts of the interest with respect to the research, authorship and/or publication of this article.

UniversePG I www.universepg.com

\section{REFERENECES:}

1) Axelsson J., Nilsson U., Terrazas E., Aliaga T. Alvarez and Welander U. (2006). Decolorization of the textile dyes Reactive Red 2 and Reactive Blue 4 using Bjerkandera sp. Strain BOL 13 in a continuous rotating biological contactor reactor. Enzyme and Microbial Technology, 39(1): 32-37. https://doi.org/10.1016/j.enzmictec.2005.09.006

2) Ayed L., Khelifi E., Jannet H. B., and Bakhrouf A. (2010). Response surface methodology for decolor-ization of azo dye Methyl Orange by bacterial consortium: Produced enzymes and meta-bolites characterization. Chemical Engineering J., 165(1): 200-208.

3) Barapatre A., Aadil K. R.and Jha H. (2017). Biodegradation of Malachite Green by the Ligninolytic Fungus Aspergillus flavus. CLEANSoil, Air, Water, 45(4): 1600045. https://doi.org/10.1002/clen.201600045

4) Celia M. P. and Suruthi S. (2016 ). Textile dye degradation using bacterial strains isolated from textile mill effluent. International $J$. of Applied Research, 2(3): 337-341.

5) Çetin D. and Dönmez G. (2006). Decolorization of reactive dyes by mixed cultures isolated from textile effluent under anaerobic conditions. Enzyme and Microbial Technology, 38(7): 926-930.

https://doi.org/10.1016/j.enzmictec.2005.08.020

6) Chindah A. C., Braide S. and Sibeudu O. C. (2004). Distribution of hydrocarbons and heavy metals in sediment and a crustacean (shrimps - Penaeus notialis) from the Bonny/ New Calabar River Estuary, Niger Delta. African J. of Environmental Assessment and Management, 9: 1-17.

7) Daneshvar N., Khataee A. R., Rasoulifard M. H. and Pourhassan M. (2007). Biodegradation of dye solution containing Malachite Green: optimization of effective parameters using Taguchi method. J. of Hazardous Materials, 143(1-2): 214-219.

https://doi.org/10.1016/j.jhazmat.2006.09.016

8) Dellamatrice P. M., Silva-Stenico, M. E., Moraes L. A., Fiore M. F. and Monteiro R. T. (2017). Degradation of textile dyes by Cyano- 
bacteria. Brazilian J. of Microbiology, 48(1): 25-31. https://doi.org/10.1016/j.bjm.2016.09.012

9) Farhana K., Syduzzaman M. and Munir M. S. (2015). Present Status of Workers in ReadyMade Garments Industries in Bangladesh. European Scientific Journal, 11(7). http://eujournal.org/index.php/esj/article/view/53 $\underline{41}$

10) Hossen M. Z., Hussain M. E., and Azad A. K. (2019). Bio-degradation of reactive textile dye Novacron Super Black $G$ by free cells of newly isolated Alcaligenes faecalis AZ26 and Bacillus spp obtained from textile effluents. Heliyon, 5(7): 1-11. https://doi.org/10.1016/j.heliyon.2019.e02068

11) Hossen MZ, Akhter $S$, Tahmina, and Khatun M. (2020). Decolor-ization and degradation of reactive blue dye used in jute and textile industries by a newly isolated Bacillus sp. Am. J. Pure Appl. Sci., 2(5), 167-176. https://doi.org/10.34104/ajpab.020.01670176

12) Islam M. M., Mahmud K., Faruk O. and Billah M. B. (2011). Textile Dyeing Industries in Bangladesh for Sustainable Development. International J. of Environmental Science and Development, 2: 428-436.

13) Jadhav S. B., Phugare S. S., Patil P. S. and Jadhav J. P. (2011). Biochemical degradation pathway of textile dye Remazol red and subsequent toxicological evaluation by cytotoxicity, genotoxicity and oxidative stress studies. International Biodeterioration \& Biodegradation, 65(6): 733-743.

https://doi.org/10.1016/j.ibiod.2011.04.003

14) Kabra A., Khandare R., Kurade M.and Govindwar S. (2011). Phytoremediation of a sulphonated azo dye Green HE4B by Glandularia pulchella (Sweet) Tronc. (Moss Verbena). Environmental Science and Pollution Research, 18: 1360-1373.

https://doi.org/10.1007/s11356-011-0491-7

15) Kalme S. D., Parshetti G. K., Jadhav S. U. and Govindwar S. P. (2007). Biodegradation of benzidine based dye Direct Blue-6 by Pseudomonas desmolyticum NCIM 2112. Bioresource Technology, 98(7): 1405-1410.

https://doi.org/10.1016/j.biortech.2006.05.023
16) Kant R. (2012). Textile dyeing industry an environmental hazard. Natural Science, 04. (01). https://doi.org/10.4236/ns.2012.41004

17) Kurade M. B., Kagalkar A. N. and Govindwar S. P. (2012). Decolorization of textile industry effluent containing disperse dye Scarlet RR by a newly developed bacte-rial-yeast consortium BL-GG. Chemical Eng-ineering J., 184: 3341. https://doi.org/10.1016/j.cej.2011.12.058

18) Kurade M. B., Waghmode T. R., and Govindwar S. P. (2017). Moni-toring the gradual biodegradation of dyes in a simulated textile effluent and development of a novel triple layered fixed bed reactor using a bacteriumyeast consortium. Chemical Engine-ering J., 307: 1026-1036.

https://doi.org/10.1016/j.cej.2016.09.028

19) Lalnunhlimi S. and Krishnaswamy V. (2016). Decolorization of azo dyes (Direct Blue 151 and Direct Red 31) by moderately alkaliphilic bacterial consortium. Brazilian J. of Microbiology, 47(1): 39-46. https://doi.org/10.1016/j.bjm.2015.11.013

20) Lin S. H. and Peng C. F. (1994). Treatment of textile wastewater by electrochemical method. Water Research, 28(2): 277-282. https://doi.org/10.1016/0043-1354(94)90264-X

21) Mali P. L., Patil D. P.and Kulkarni M. V. (2000). Biodecolourisation of members of triphenylmethane and azo group of dyes. J. of Scientific and Industrial Research, 59: 221-224.

22) Mishra A. and Malik A. (2014). Novel fungal consortium for bioremediation of metals and dyes from mixed waste stream. Bioresource Technology, 171: 217-226. https://doi.org/10.1016/j.biortech.2014.08.047

23) Mohan S. V., Rao N. C., and Karthikeyan J. (2002). Treatment of simulated Reactive Yellow 22 (azo) dye efflu-ents using Spirogyra species. Waste manag., 22(6): 575-582. https://doi.org/10.1016/s0956-053x(02)00030-2

24) Mona E. M. and Yusef H. (2008). Decolorization of fast red by Bacillus subtilis HM. Journal of Applied Science and Research, 4(3): 262-269.

25) Pandey A., Singh P. and Iyengar L. (2007). Bacterial decolorization and degradation of 
azo dyes. International Biodeterioration \& Biodegradation, 59(2): 73-84.

https://doi.org/10.1016/j.ibiod.2006.08.006

26) Patel V. R., Bhatt N. S.and Bhatt H B̀. (2013). Involvement of ligninolytic enzymes of $M$. vellerea HQ871747 in decol-orization and complete mineralization of Rea-ctive Blue 220. Chem. Eng. J., 233: 98-108.

27) Rahman MA, Ahmad T, Mahmud S, Uddin ME, and Ahmed R. (2019). Isolation, identification and antibiotic sensitivity pattern of Salmonella spp. from locally isolated egg samples, Am. J. Pure Appl. Sci., 1(1), 1-11. https://doi.org/10.34104/ajpab.019.019111

28) Rovira J. and Domingo J. L. (2019). Human health risks due to exposure to inorganic and organic chemicals from textiles: A review. Environmental Research, 168: 62-69.

https://doi.org/10.1016/j.envres.2018.09.027

29) Saratale RG., Gandhi SS., and Saratale GD. (2013). Decolorization and detoxification of sulfonated azo dye C.I. Remazol Red and textile effluent by isolated Lysinibacillus sp. RGS.J.of Biosci. and Bioeng., 115(6):658-667. https://doi.org/10.1016/j.jbiosc.2012.12.009

30) Shah M. P., Patel K. A., Nair S. S. and Darji A. M. (2013). Molecular characterization and optimization of Azo dye degrading B. subtillis ETL-2013. OA Molecular and Cell Biol., 1(1): 2. https://doi.org/10.13172/2054-7331--1-651

31) Shah P. D., Dave S. R. and Rao M. S. (2012). Enzymatic degradation of textile dye Reactive Orange 13 by newly isolated bacterial strain Alcaligenes faecalis PMS-1. International Biodeterioration \& Biodegradation, 69: 41-50. https://doi.org/10.1016/j.ibiod.2012.01.002

32) Shen N., Huo Y.C., and Zeng R. J. (2015). Decolorization by $C$. saccharolyticus with dissolved hydrogen under extreme thermophilic conditions. Chem. Engin. J., 262: 847853. https://doi.org/10.1016/j.cej.2014.10.053
33) Shuchismita D. and Ashraful I. (2015). A Review on Textile Wastewater Characterization in Bangladesh. Res. and Env., 5: 15-44. https://doi.org/10.5923/j.re.20150501.03

34) Staley J. R., Boone A. R., and Schleifer K. H. (2001). Bergey's Manual® of Systematic Bacterio-logy. Springer $2^{\text {nd }}$ Edition.

35) Stiborova M., Dracinska H., and Frei E. (2013). Induced expression of cytochrome P450 1A and NAD(P)H: quinone oxidoreductase determined at mRNA, protein, and enzyme activity levels in rats exposed to the carcinogenic azo dye 1-phenylazo-2-naph-thol (Sudan I). Chem. Res. Toxic., 26(2): 290-299.

36) Uddin M. E., Ray S. K., and Ahammed T. (2017). Thermotolerant extracellular proteases produced by $B$. subtilis isolated from local soil that representing industrial applications. J. of Pure and Applied Microbiol. 11(2), 733-741. https://doi.org/10.22207/JPAM.11.2.12

37) Veena S., Rao B. and Venkata K. (2019). Biodegradation of Textile Azo Dyes. Nanoscience and Biotechnology for Environmental Applications. Cham, Springer International Publishing: 115-139.

38) Wang Z. W., Liang J. S. and Liang Y. (2013). Decolorization of Reactive Black 5 by a newly isolated bacterium Bacillus sp. YZU1. Intern. Biodeterioration \& Biodegradation, 76: 41-48. https://doi.org/10.1016/j.ibiod.2012.06.023

39) Wanyonyi W. C., Onyari J. M.,. and Mulaa F. J. (2017). Biodegradation and Detoxification of Malachite Green Dye Using Novel Enzymes from $B$. cereus Strain KM201428: Kinetic and Metabolite Analysis. Ener. Proc., 119: 3851. https://doi.org/10.1016/j.egypro.2017.07.04

40) Yadav A. (2014). Toxic characterization of textile dyes and effluents in relation to human health hazards. Journal of Sustainable Environmental Research, 3(1): 95-102.

Citation: Hossen MZ, Akhter S, Rahman T, Tahmina, and Khatun M. (2020). Bacterial degradation of synthetic dye by Pseudomonas sp. obtained from dyeing mill effluent, Am. J. Pure Appl. Sci., 2(6), 192-199.

https://doi.org/10.34104/ajpab.020.01920199 () क्ष 